\section{AERONATTICAL MOTES.}

THE AERONAUTIC BOCETTY AEROPLANE.

It was announced on March 3rd at a meeting of the Aeronautic Society by Lee $\mathbf{S}$. Burridge, the president, that he had concluded a contract for the purchase of a $\$ 5,000$ aeroplane for the Society's first public exhibition this year at Morris Park.

The contract is with Glenn $\mathrm{H}$. Curtiss, of Hammondsport, N. Y., member of Dr. A. Graham Bell's well-known Aerial Experiment Association, who, in the Association's aeroplane, the "June Bug," built at his factory, has made many successful fights at Hammondsport, chief of which were those of July ith last, when he won for the first time the Scientific American trophy.

Arrangements have also been made with Mr. Curtiss for him to give public demonstrations of fiight for the Society at Morris Park. The Society is converting the old race-track into a first-class aerodrome. The grandstand will accommodate thousands of spectators who will undoubtedly gather there to see Curtiss fiy, and to witness the aeroplane races which will take place.

The Aeronautic Society is thus the first aeronautical body in America to purchase an aeroplane.

The first public fiights by Mr. Curtiss in New York city are to be made at Morris Park early in the month of May.

In describing the new machine, Mr. Curtiss states that it will be in many ways different from the aeroThe main surfaces, of about 30 by 4 feet, will be parallel and not arched as in the "June Bug." It will have front and rear rudders controlled entirely by the aviator. The transverse stability will be maintained automatically by a new device. There will be many features that are novel, although not untried. The weight will be about 600 pounds, which is much lighter than the average of the machines now fiying. The aeroplane will be capable of lifting 200 pounds. The engine will be a 4-cylinder, water-cooled motor of 25 horse-power, which experience has taught is sufficient. The propeller, of $5 \frac{1}{2}$ feet diameter and the same pitch, will be mounted upon the engine crankshaft at the rear. The frame of the aeroplane will be of spruce wood and the surfaces of rubber-impregnated silk.

The aeroplane will be mounted upon a 3 -wheeled chassis, and it can be started either by running along on the ground under its own power or by being jerked suddenly forward ' by a falling weight, as is the miles an hour, and Mr. Curtiss expects to make several new records with it.

a NeW aebonautic manufacturing company.

Immediately following the news of the purchase of an aeroplane by the Aeronautic Society came the announcement last week of the formation of a $\$ 300,000$ company organized by Mr. C. F. Bishop, the president of the Aero Club of America, for the manufacture of aeroplanes and dirigibles. A. M. Herring, the aeroplane inventor who is under contract to supply the government with a 2-man machine by next June, has a large interest in the new company, to which he will assign his American patents upon automatic stability devices, etc., when they issue. G. H. Curtiss is also a principal stockholder, and for the present the aeroplanes and motors will be built at his plant at Ham mondsport, N. Y. The aeroplanes to be produced are to have all the improvements devised by Herring and Curtiss, and they are to sell at $\$ 7,500$ each. It is also proposed to build gliders for $\$ 600$. Capt. T. A. Baldwin will attend to the manufacture of dirigible balloons, several of which will be constructed shortly. The co-operation of the leading experimenters in both lighter-than-air and heavier-than-air apparatus should do much toward furthering a rapid development of aeronautics in America.

\section{An Important Reduction of Magnetic \\ Observations.}

The variation of the magnetic needle with time and place is a matter of such vital interest to the navigator and the land surveyor, not to mention the scientific investigator, that the study and publication of data bearing on this phenomenon regularly must be undertaken under government or other auspices that will insure accuracy and completeness. The navigator must have information which will enable him to correct the courses as indicated by his compass, and the surveyor in running the lines of a piece of land as given in an old deed or other description must be able to allow for the change in direction of the old compass bearings. Therefore much practical importance attaches to the work of the Division of Terrestrial Magnetism of the United States Coast and Geodetic Survey, and this among persons interested has been heightened by the recent publication of "United States Magnetic Tables and Magnetic Charts for 1905." In past years it has been the custom of the Coast Survey to prepare magnetic charts for some period in advance of the date of issue, but the greater attention recently paid to magnetic studies makes it evident that the secular changes on which such charts are prepared are none too well understood in detail. Accordingly it was decided to prepare tables and charts for the year 1905 corrected to that date with all possible precision, and in the light of observations rather than the estimates. The work involved in this volume was under the direction of $\mathrm{Dr}$. L. A. Bauer,' who in the fall of 1906 resigned from the Survey to become director of the Department of Terrestrial Magnetism of the Carnegie Institution, and the great development into a harmonious and comprehensive plan under which magnetic research has been and is being carried on by these two agencies is in large measure due to his efforts.

Terrestrial magnetism aside from its practical application, represents an interesting aspect of modern science. Ordinarily. we conceive of the processes of nature as involving long periods of time, as in the formation of continents or in the evolution of animal forms, or at the other extreme some sudden cataclysm as an earthquake, so that when a series of natural phenomena involving a swift and ceaseless change in so short a period as five or ten years is occurring, as in the earth's magnetism, it is indeed difficult to realize and understand it. In fact the problem becomes more difficult in the development of present-day science. In the early part of the nineteenth century a famous scientist remarked that once discovered the laws of nature were simple, but to-day that statement hardly can hold where a wealth of data obtained by observation and experiment often shows conclusively that the laws of nature are complex to an extreme. Thus in looking at charts of equal magnetic declination, inclination and intensity it will be noted that the lines showing these quantities are very irregular and are not the smooth fiowing curves by which the distribution of the earth's magnetic force on land once was indicated.

Local and other conditions, shown by a number of observations, are such that to-day the irregular curves are the normal ones, and those that ar regular either must be dismissed as conventional drawings or considered as based on an inadequacy of observation. The work recently published gives tables of the observed magnetic elements at many points in the United States as far as available and their values reduced to the date January 1,1905 , from observations made at over 3,300 stations, over two-thirds of which were occupied by. the Survey from 1899 to 1906.

These stations averaged about 31 miles apart with an average of one for every 973 square miles. The observations were made on a common system and in strumental errors so far as possible were eliminated. In addition observations were made at sea from the vessels of the Survey. The charts accompanying the tables show declination, inclination, horizontal in tensity, vertical intensity, total intensity, magnetic meridians, and secular motion and horizontal intensity secular variation eurves.

\section{The Current Supplement.}

The current Suppiement, No. 1732, opens with a strikingly illustrated article on three bird habitat groups which have recently been mounted in the American Museum of Natural History. One group shows the duck hawk and its nest on the Hudson Palisades. Another group illustrates bird life in the New Jersey Hackensack Meadows in August; and the third shows part of a colony of white egrets of South Carolina. Other articles that deserve to be mentioned are those entitled "New Process for the Impregnation of Timber," "Vacuum Distillation;" "A Model Atom," "Chemical Effects of Magnetism, "Limit to the Number of Marine Organisms." Dr. H. Decker writes instructively on the subject "Man as Machine." An estimate is made of the available coa supply of the United States. Percy Longmuir contributes an article on Alloys. Hudson Maxim's imasinative artiele on the "Warfare of the Future" is concluded. Somewhat allied is the article on military tactics and the dirigible airship. Prof. Reginald Fessenden contributes by far the most important article in the Supplement, namely, that on wireles telephony, in which he traces its history and present status. G. K. Gilbért's admirable study of Earthquake Forecasts is concluded. The usual Engineering, Science, and Trade Notes are also given.

\section{A Chance for Rubber Heel Inventors.}

The inventor of a well-known, widely-advertised rubber heel for shoes has expressed a desire to examine patents covering rubber heels, or even mere ideas. Inasmuch as many readers of this journal are in ventors of rubber heels, it will give the Editor pleasure to place them in communication with th is manufacturer. Inquirers should send in printed copies of their patents to be forwarded, if their ideas are patented.

\title{
THE M'CALL'S FERRY HYDRO-ELECTRIC POWER
} PLANT.

A most notable hydro-electric engineering project is being carried out on he Susquehanna River. It is an interesting fact that this water course, although one of the most important in the United States, has been literally running to waste. Although the river drains an area of nearly 30,000 square miles and is 350 miles in length, as yet the power developed from it has been so small as to be insignificant in comparison with what can be obtained by the plant we have referred to.

In a distance of 60 miles examined by engineers, it is estimated that this river would afford over 400 , 000 electrical horse-power, were a series of dams and generating stations installed where sites are available. The McCall's Ferry dam, as it is termed, has been built on this section at a site where it is calculated fully 150,000 horse-power can be developed. While the river is very wide at this point, an island dividing it into two channels enabled the builders to construct a barrier where the volume of water and the current at fiood height might otherwise have rendered the project impossible. As it is, plans had to fields which come down the river with the spring freshets, also to provide for the great difference between the height of the river at high water and at low water, which at times is no less than 30 feet. The total width of the Susquehanna at McCall's Ferry is nearly 3,000 feet, consequently a barrier of these show, the dam is an imposing structure. In height it ranges from 60 feet to 100 feet, while its width at the bottom is no less than 68 feet, tapering to the crest in a parabolic curve. An idea of the amount of material in the work is given when it is stated that nearly 400,000 cubic yards of concrete were set before it was completed. As the illustrations show, it is of the ogee type, designed especially to withstand the ice packs, also the debris which is brought down on flood currents in addition to the great volume of water.

For a distance of 2,650 feet the McCall is a dam of the weir type. Consequently, it is believed that the annual fiood will carry the fioating matter over it without doing damage, since the river reaches such a height in fiood time that the depth of water on the crest of the dam will at times be fully 15 feet. The sides of the barrier, however, have been constructed of a special thickness, and are considerably higher than the weir section, being built at such an angle that they do not offer direct resistance to the water course. In fact, the engineers have taken advantage of curves and angles wherever possible, so as to divert the force of the fiood current.

The building of the main dam and the power canal necessitated much preliminary work, owing to the difficulties of placing a barrier across this wate course. It was necessary for the false work to be of the most substantial character, and one of the first steps was the construction of ajother massive viaduct nearly across the river. This outlay alone was $\$ 200$, 000 , because the bridge was 2,000 feet in length with a width of 50 feet, on which were laid four railway tracks. The work was necessary in order to furnish a site for the concrete and other supplies and for the mechanical conveyors which transferred the material into the bridge forms. Although the viaduct was in itself a structure which might be considered permanent, it was only built for the purpose of facilitating the construction of the dam in lieu of wooden and other false work, and was later destroyed.

It was necessary to build a cofferdam of unusual strength to meet the emergency. Work was begun upon this from the east side of the river, and the water diverted from a section of the channel about threefourths of a mile in width. Here the permanent structure was taken up, the barrier being formed in piers with a space of about 50 feet between each. After this section was completed, a second cofferdam was built from the west side, and the operation was repeated. Thus the dam in sections extended across the river, but owing to the method of construction, the spaces between the piers, left to allow. the water to fiow through during the work, are easily being closed, as operations can be carried on without hindrance from the rise and fall of the river. The plan of build ing the cofferdam was to construct huge timber cribs, 16 foet by 35 feet, their bottoms being modeled to fit 
building 200 feet by 50 feet. The mixers were placed under chutes connecting with bins above, which contained the crushed stone, sand, and cement used in the mixing. There were 32 of these bins in all. Next to the concrete plant a

store house for the cement was erected. All the drills and the hoists on the derricks were worked by compressed air, furnished by two 350-horse-power Corliss engines. In the same engine house was inatalled the dyamo that furinis es t h e entire works, houses, etc., with electric lighting and telephone service.

At Conowingo, 14 miles below McCall's Ferry, the company opened two immense quarries, giving employment to 400 men. The quarries are about a mile apart, one having a rock face 2,000 feet long and the other a rock face 1,000 feet a rock 1,000 feet long. Bot quarries are adequately racked, it is taken from the quarries is swung out over the tracks on large cables and then dumped into cars These cars are drawn by engines to crusher, which the company has erected near the railroad station at Conowingo. The sand for the concrete is dredged from the bottom of the Chesapeake Bay off Elk River and brought to Port De- posit on a fleet of ten barges. As soon as it arrives port Deposit it is taken from the barges by two suction pumps and dumped into the waiting cars, which haul it up to McCall's

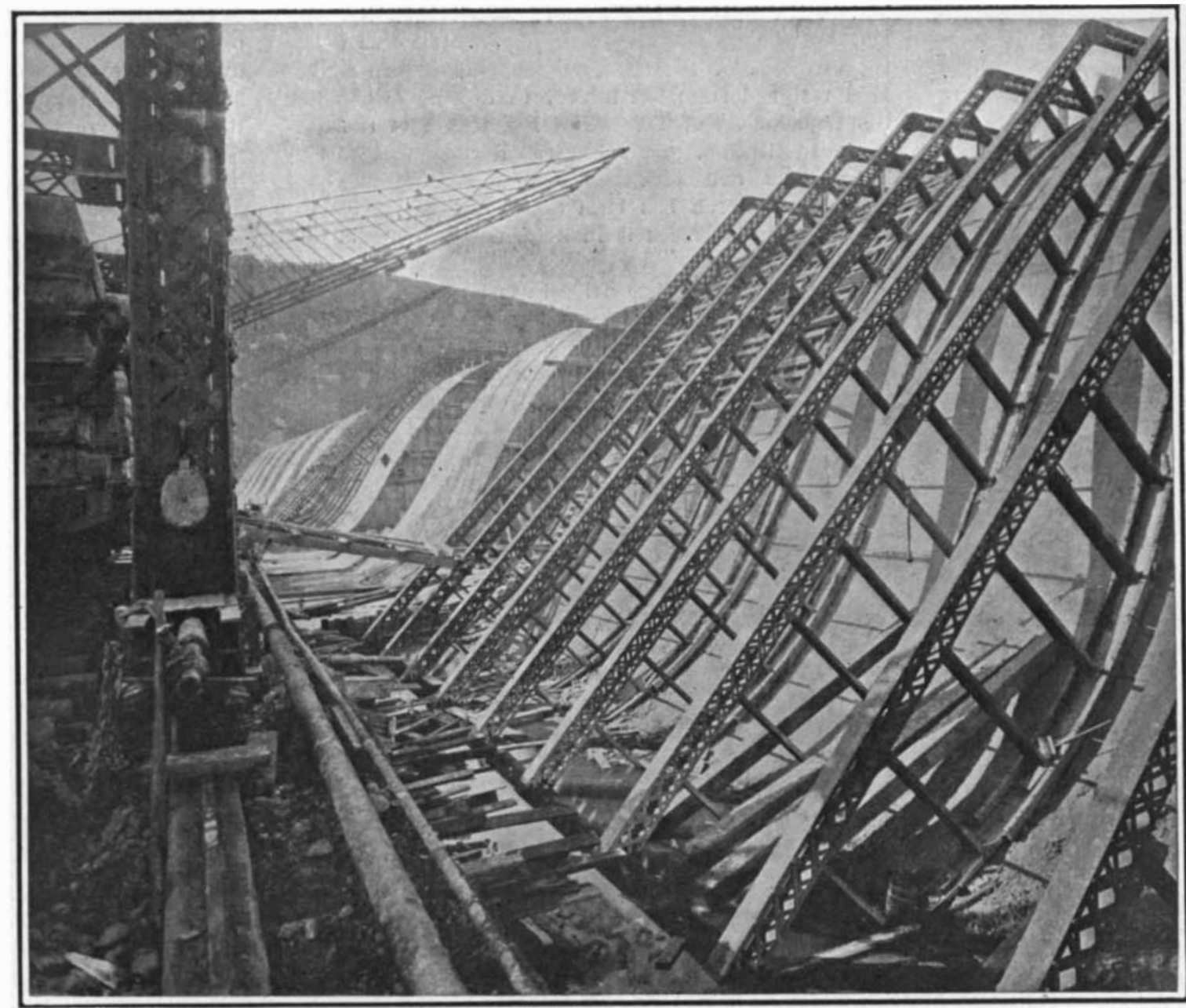

View showing the steel forms used in molding the face of the dam.
Ferry, a distance of 21 miles. The power house, which contains the electrical installation, is 80 feet by 500 feet and is equipped with ten Swiss twin-turbine motors, parallel outward flow, each with capacity to generate 13,500 horse-power. The 13,500 horse-power. The water which turns the passes through ten large conduits to the wheels at the rat of 16,000 gallons a second. After turning the wheels, this water is discharged into the old river bed below the dam The main difference between this plant and the ones at Niagara lies in the fact that no wing dam had to be built and that the water furnishing the power, instead of passing to the turbine wheels through conduits, drops down into rectangular pits in which are located the turbine wheels This in stallation will give the McCall's Ferry plant tise largest capacity of any in the United States with the exception of those at $\mathrm{Ni}$ agara Falls. The size of the power house can be appreciated by noting its dimensions. It is one of the most complete of its kind in the country, being equipped with permanent electrical apparatus for lifting and transferring parts of generating units and other heavy machinery which may be in-

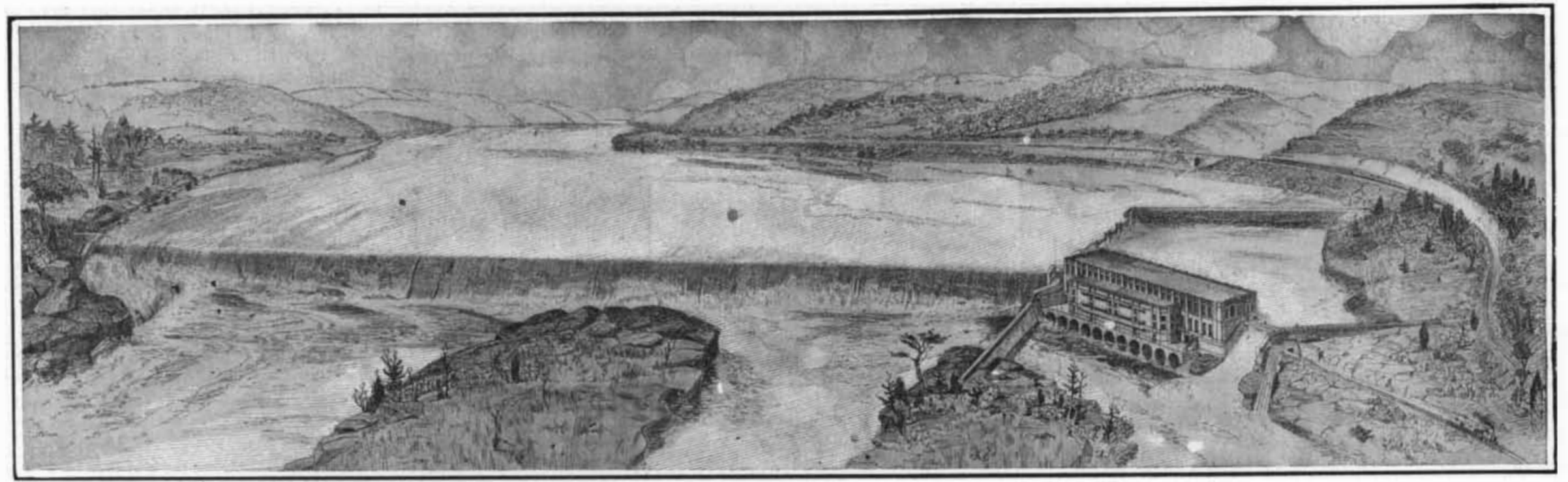

View of the McCall's Ferry dam and hydro-electric power plant as it will look when completed.

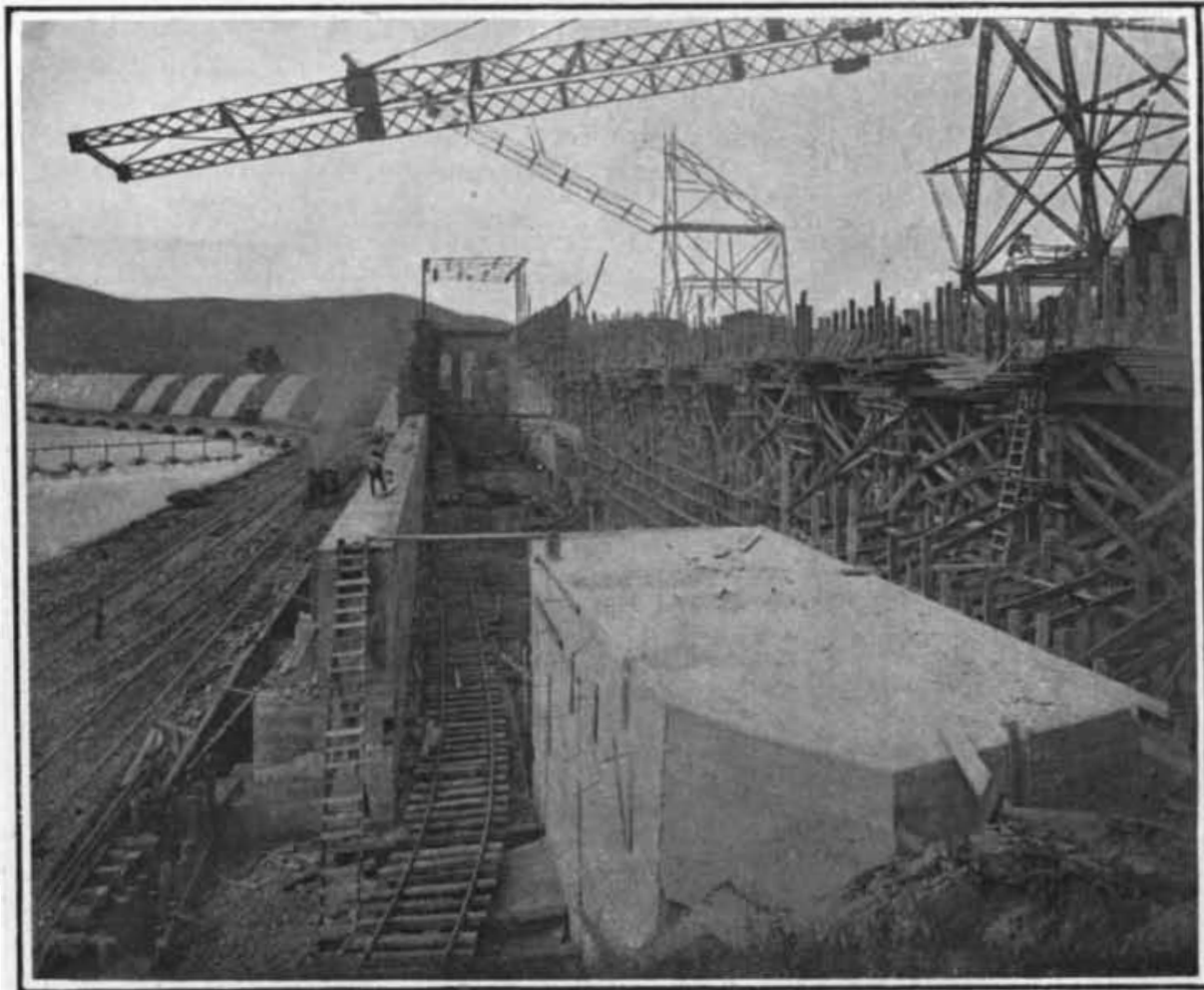

Details of the power honse construction, showing conveýors and concrete molds.

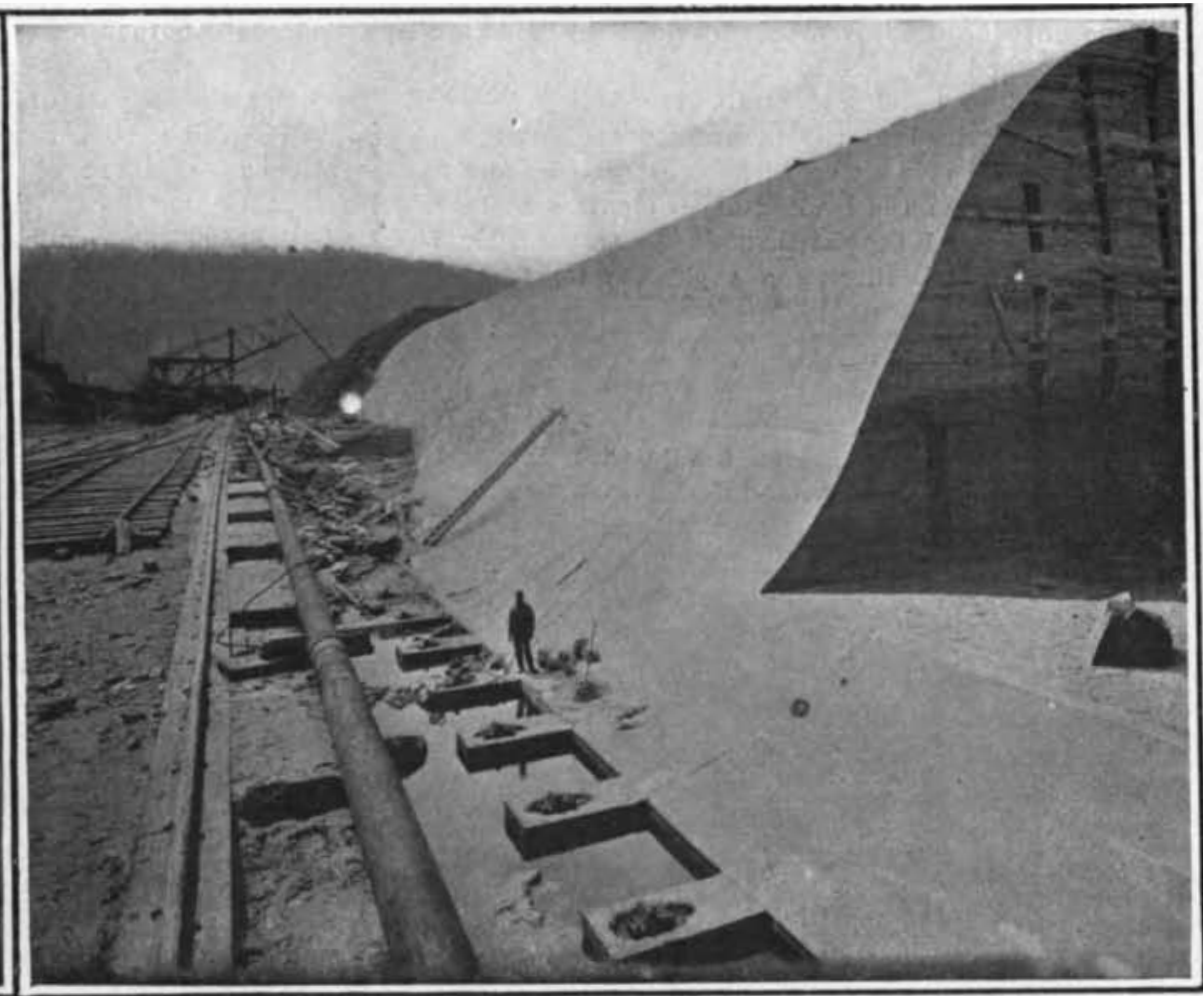

Section of dam complete, showing proportions as compared with the size of a man. 
stalled in future. The lifting and conveying mechanism is operated by an individual motor plant.

Within a radius of 75 miles from the site of the pro ject are situated a number of manufacturing centers, including the cities of Baltimore, Washington, Harrisburg, York, Lancaster, and Philadelphia with the



Front view of the aeroplane, showing horizontal and vertical rndders, radiator, and steering wheel.: The machine is mounted upon runners placed below its central portion.

present system of electrical transmission for power, the current can be conveyed to any of these points. Consequently, the location is adjacent to a very large source of consumption, saying nothing of an extensive mileage of street and interburban railways, which it may furnish with current. Although the current will have to compete with' steam, as 'fuel in this part of the country is sold at a very low price, owing to the proximity of the 'soft coal mines, the calculations of the electrical engineers are that electrical power can be generated and supplied to any 'point in the' entire territory at a lower cost than steam power can possibly be generated, owing to the character of the generating machinery and the low cost and abundance of the water power.

The plan of the promoters to serve such a wide field with electric power, in spite of the competition due to the low price of steam coal, will be followed with interest, for the reason that nearly all of the generating stations recently built on water-power sites have been in sections where it was impossible for industries. to be supplied with coal or other fuel except at a very high price, usually far in excess of the rates paid by manufacturers in the radius of McCall's Ferry for fuel.

Altogether, the project represents an investment of about $\$ 10,000,000$. It has been taken up after an investigation made by Mr.' William Barclay Parsons $\mathrm{Mr}$. Cary T. Hutchinson, and other noted experts. The work was done under the general supervision of $\mathrm{Mr}$. Hutchinson.

\section{TEBT OF THE BELL TETRAHEDRAL-CELL $\triangle$ EROPLAIE} IN NOVA SCOTIA.

The accompanying photographs show Dr. Alexander Graham Bell's aeroplane "Cygnet II;" which was recently tried in Nova Scotia.. The construction of the "Cygnet I" has already been described in our columns, this being on the principle of the tetrahedral kite. Dr. Bell's idea is that the difficulty experienced in aeroplanes composed of a few large planes, of maintaining the center of air-pressure coincident with the center of gravity, may be overcome by dividing the supporting and guiding planes into as large a number as possible of tetrahedral cells; as the center of air pressure upon any one pocket cannot move outside the area of that pocket, the center of pressure of the whole structure cannot move over a proportionally larger area.

This system of construction has the further advantage that the size of the machine may be indefinitely increased with an increase of weight only

of a few large planes, the necessary strength of construction causes the weight to increase as the cube of the dimensions.

In December, 1907, Dr. Bell tested the "Cygnet I" by towing it as a kite above Lake Bras d'Or, near Baddeck, N. S. Upon that occasion the late Lieut. T. E.
The "Cygnet II" is larger and somewhat different shaped than its predecessor. As can be seen from the photographs, it is composed of a great number of tetrahedral cells, or V-shaped surfaces. The 8-cylinder $\mathrm{V}$ motor and radiatior are mounted upon the rear of a triangular frame extending through a cut-away part of the aeroplane, at the center, while the aviator's seat is at the front of this frame. The motor, of $3 \%$ inch bore by 4 -inch stroke, develops 35 horse-power at $1,000 \mathrm{R}$. P. M. It drives the large propeller by means of sprockets and chain. The propeller makes 1,500 R. P. M. to 1,000 of the motor. This engine will develop 50 horse-power and it weighs complete, but without water, 202 pounds.

A double-surface horizontal rudder and a single vertical rudder are arranged upon a bamboo frame that projects out in front. Both rudders can be operated by a single steering wheel. The aeroplane is mounted upon three runners for the purpose of testing it upon ice.

It was not supposed that the power of the engine would be enough to start the machine or even to maintain a sufficient speed to support it in flight, but it was proposed to determine, by observation of the difference between the towing force required to keep the machine suspended with and without the engine, how much power would be required in free flight.

Unfortunately, however, the propeller shaft sheared Unertunate howere th tained. That the fault was not with the engine was sufficiently proved by the later success of the latter in the aeroplane "Silver Dart" to which it was transferred.

After having previously made over a dozen practice flights at Hammondsport, N. Y., Mr. J. A. D. McCurdy flew completely around Lake Bras d'Or, a distance of about $41 / 2$ miles, at ${ }^{\prime}$ a speed of about 40 miles an hour and at an elevation of about 30 feet, on February 24th.

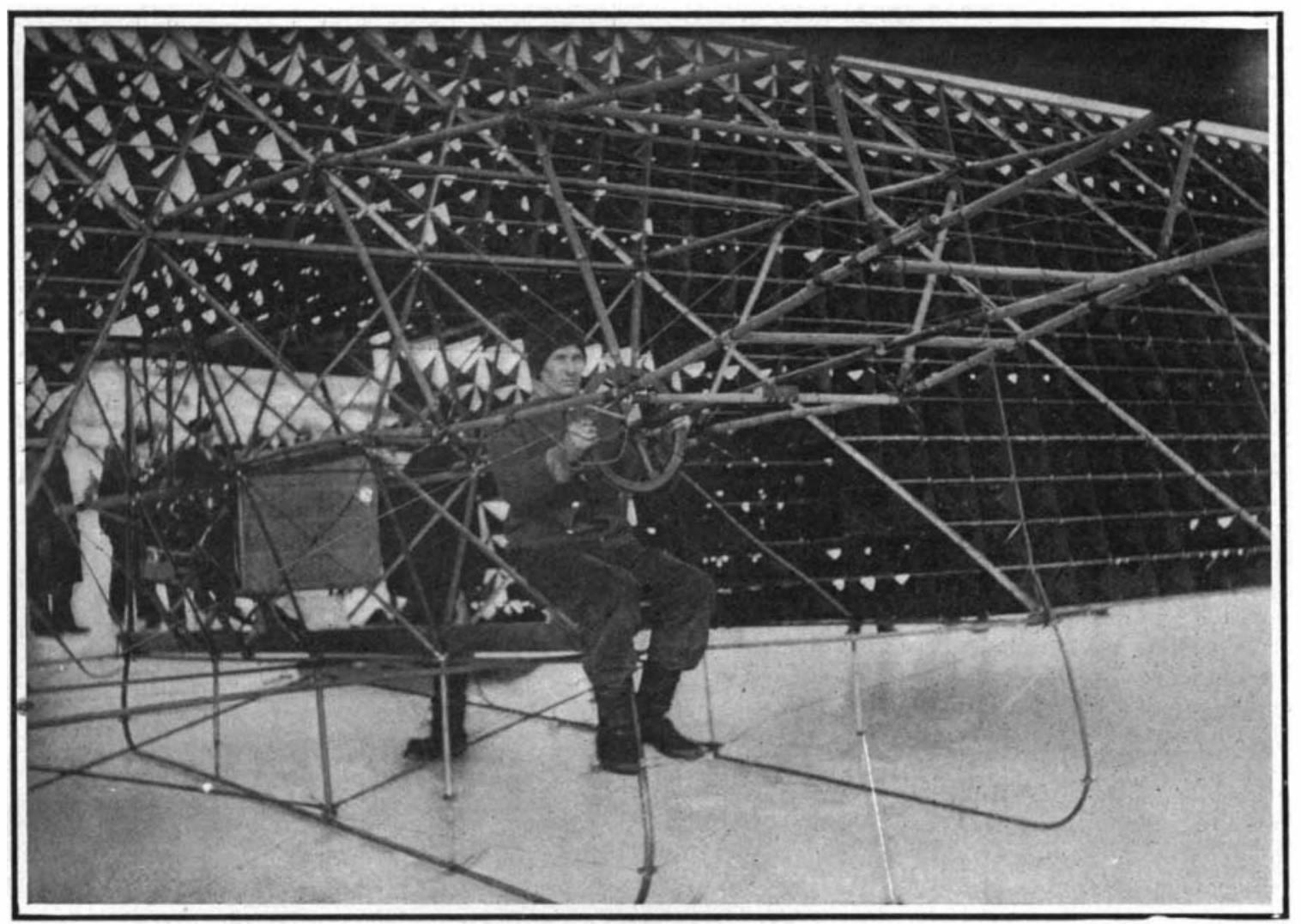

The aviator and power plant of the o Cygnet II."

Much of the framework is constructed of bamboo. The aviator sits at the front end of a triangular body frame while the motor and radiator are located at the rear of this frame.

Selfridge went up to a height of 168 feet, and remained aloft for seven minutes. He was greatly impressed with the stability of the kite and the feeling of security he had when in it. An illustrated account of this test was published in Supplement No. 1681 .
A trial flight of half a mile made the day before was the first to be made by any motor-driven aeroplane in Canada. Mr. McCurdy is anxious to compete for the ScienTIFIC AMEricay Trophy, and he may attempt to make the 25-kilometer flight required before he returns.



Rear view of the aeroplane, showing its shape and the arrangement of the tetrahedral cells. The large wooden propeller is chain-driven from the 8-cylinder engine placed below.

FIRST TEST OF THE BELL TETRAHEDRAL-CELL AEROPLAT

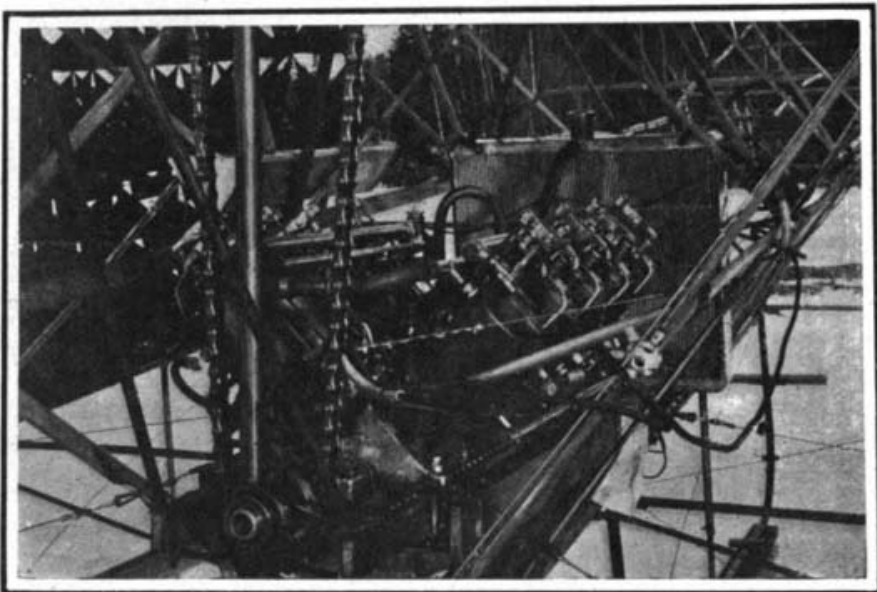

The 50-horse-power, 8-cylinder water-cooled Curtiss motor. The valves are of the concentric type, mechanically operated. Copper water jackets 


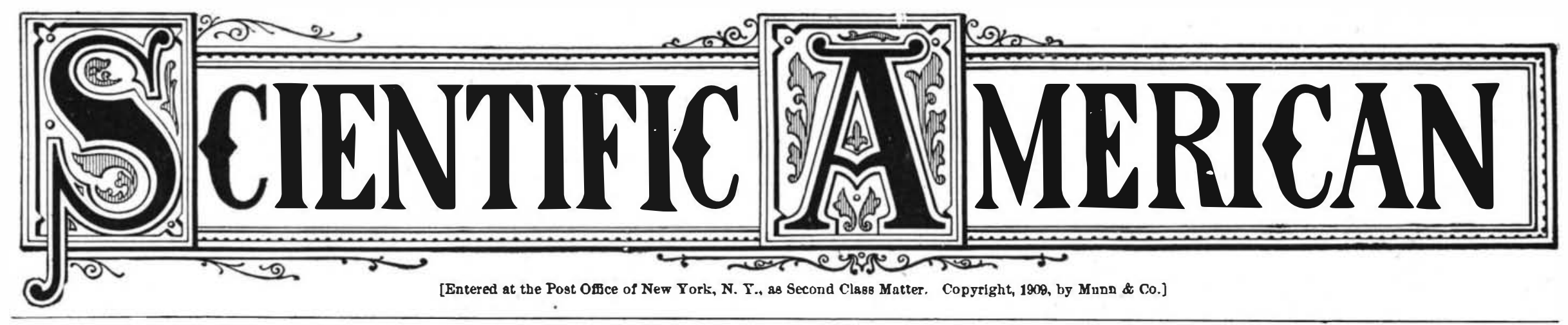

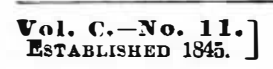

NEW YORK, MARCII 13, 1909.



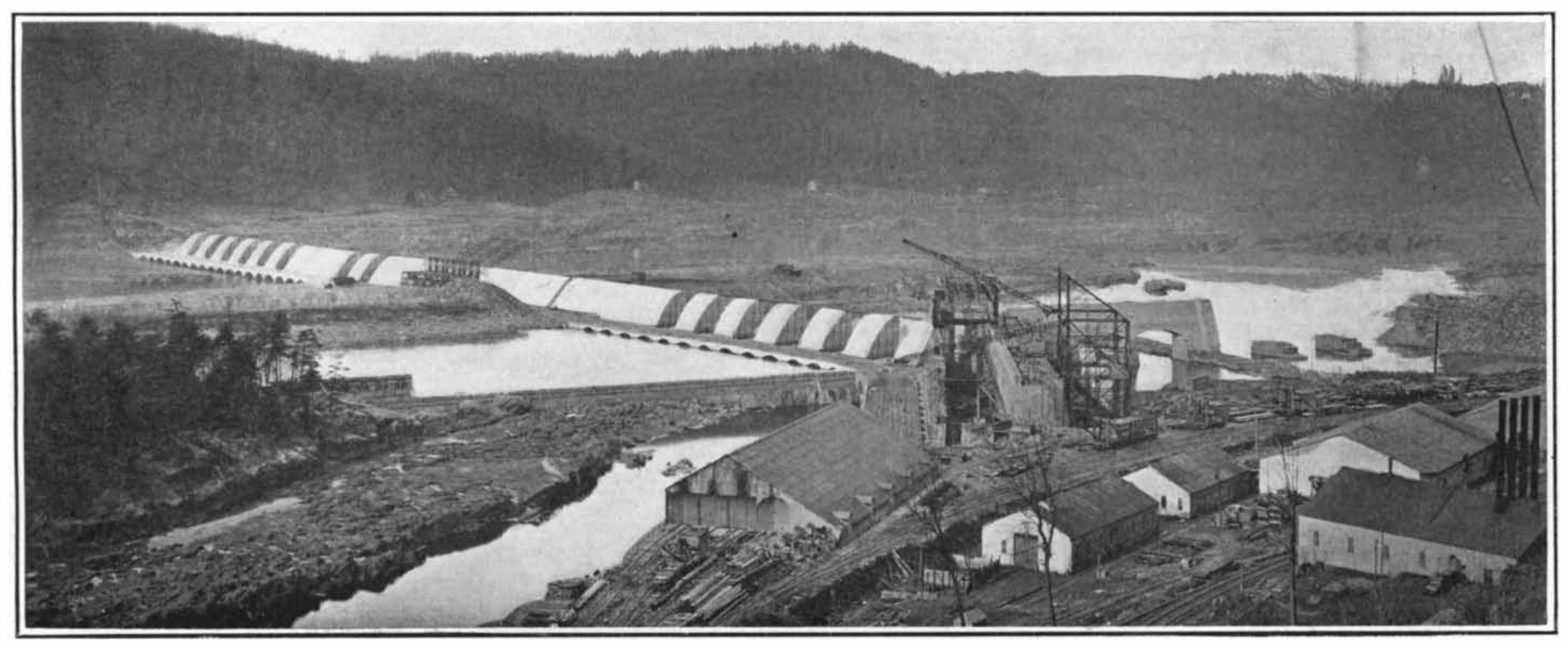

The present appearance of the dam and the partly constructed power nouse.



Bridge carrying construction line and penstocks being assembled in foreground.

THE M'CALL'S FERRY HYDRO.ELECTRIC POWER PLANT. - [See page 203.] 